\title{
Management of the anticipated difficult airway-a systematic approach: Continuing Professional Development
}

\author{
Pierre Drolet, MD
}

Received: 9 May 2009/Accepted: 17 June 2009/Published online: 28 July 2009

(c) Canadian Anesthesiologists' Society 2009

\begin{abstract}
Purpose The purpose of this Continuing Professional Development module (CPD) is to update clinicians regarding a systematic approach for anticipated difficult airway management.

Principal findings The focus of the approach should be directed towards providing adequate oxygenation and ventilation and not necessarily intubating the trachea. The purpose of preoperative airway assessment is not only to detect possible difficult direct laryngoscopy, but also to evaluate the probability of effective ventilation using supraglottic airway devices, such as the oropharyngeal airway or the laryngeal mask airway. Predicting the degree of difficulty with direct laryngoscopy or ventilation with a supraglottic device remains an imperfect science, and the experience of the anesthesiologist plays an important role in the clinical decision-making process. When a difficult airway is anticipated, the need for tracheal intubation should be carefully assessed. If tracheal intubation is deemed nonessential, the role of a supraglottic device should be considered. If adequate management with a supraglottic device is unlikely, then intubation is indicated with the patient awake. In certain cases, a sevoflurane induction may be chosen to test the efficacy of a supraglottic device while simultaneously maintaining spontaneous ventilation. If tracheal intubation is required, a supraglottic device may be used as a bridge during induction of anesthesia and may even be used to insert the tracheal tube. The choice of either the supraglottic device or another aid to intubation depends essentially on the anesthesiologist's experience.
\end{abstract}

P. Drolet, MD ( $\varangle)$

Département d'anesthésiologie, Université de Montréal, C.P. 6128, succursale Centre-ville, Montréal, QC H3C 3J7, Canada e-mail: pdrolet@aei.ca
Conclusion Airway management should be approached systematically, always keeping in mind the importance of uninterrupted oxygenation and ventilation, especially when difficulties are anticipated. Supraglottic devices can play an important role in the management of the difficult airway, whether used for the duration of surgery or inserted as an aid to intubation.

\section{Continuing Professional Development module objectives}

After reading and completing this module, the anesthesiologist should be able to:

1. Use a systematic approach for airway management;

2. Identify certain characteristics associated with a difficult airway;

3. Be aware of the importance of evaluating potentially difficult direct laryngoscopy and identify the potential for difficult ventilation with a supraglottic airway;

4. Suggest solutions for airway management in a patient with a history of difficult tracheal intubation; and

5. Define the role of different instruments for airway management.

A difficult airway may occur unexpectedly. However, this Continuing Professional Development (CPD) module focuses on the recognition and management of the anticipated difficult airway in adult patients. Although many principles outlined herein may apply to cases of unanticipated difficulties with oxygenation, ventilation, or tracheal intubation, the reader should refer to other standard references addressing these issues for a detailed review of these scenarios. 
Tracheal intubation is the primary outcome in many studies on airway management in adults. Direct laryngoscopy to perform tracheal intubation remains a core skill of anesthetic practice that all anesthesiologists must acquire early in their training. Many experts consider tracheal intubation under direct vision as the gold standard with which all other airway management techniques should be compared. However, we recognize that many techniques are now available that achieve adequate airway control without direct laryngoscopy or tracheal intubation. The key point is not necessarily to intubate the trachea, but to ensure that ventilation and oxygenation are maintained at all times, especially during maneuvers that lead to securing the airway. As airway specialists, anesthesiologists now have numerous airway devices available that act either as conduits to oxygenation and ventilation (e.g., laryngeal mask airway, laryngeal tube...) or as devices designed specifically to facilitate tracheal intubation (lighted stylets, videolaryngoscopes, flexible bronchoscopes...).

This module is not intended to replace guidelines written by expert groups. ${ }^{1,2}$ Its purpose is to provide a self-directed learning experience to foster a systematic approach for management of the anticipated difficult airway in adult patients, especially in the perioperative period.

\section{Airway assessment}

\section{Direct laryngoscopy}

The main purpose of most studies on airway management is to identify criteria to predict patients for whom orotracheal intubation with direct laryngoscopy might be difficult. Nevertheless, certain authors also attempted to identify potential problems with other intubation techniques, such as the lighted stylet, ${ }^{3}$ the intubating laryngeal mask airway $\left(\right.$ Fastrach $\left.^{\mathrm{TM}}\right),{ }^{4}$ or the videolaryngoscope. ${ }^{5}$ The number of related randomized controlled trials is limited, often leaving the clinician to rely on lower levels of evidence of case reports/case series and personal experience to define or assess the advantages and limitations of these devices. Regardless, the prediction of difficult orotracheal intubation using direct laryngoscopy is not always an easy task. ${ }^{6}$ In certain cases, the problems are obvious, such as when a patient has a large tumor or an oropharyngeal abscess, or when jaws have been surgically wired together following a fracture. On the other hand, in many patients a cursory airway examination (mouth opening and neck extension) allows the experienced anesthesiologist to anticipate an easy direct laryngoscopy and intubation. There remains a number of patients for whom the clinician would appreciate tools to accurately predict the degree of difficulty associated with direct laryngoscopy and successful intubation.

In many studies, there have been attempts to identify features and to suggest assessment techniques that predict difficult or impossible tracheal intubation using direct laryngoscopy (Table 1). Some of the identified features include obesity, a short thyromental distance, Mallampati class III or IV, decreased neck mobility, or a short distance between upper and lower incisors. More recently, evaluation of mandibular protrusion or subluxation and hyomental distance were added to the airway assessment criteria. Some of these factors or measurements assess different, but related factors influencing airway anatomy, for example body mass index and weight. Other factors, such as the extent of mandibular protrusion, provide unique information, because such movement is vital when direct laryngoscopy is difficult. However, it should be remembered that the specificity and sensitivity of these proposed criteria only allow an imprecise estimate of the degree of difficulty of tracheal intubation, especially in borderline cases. In studies dealing with the identification of criteria concerning difficult direct laryngoscopy, there were very few tracheal intubation failures using this method. When a criterion with a high specificity is present, it is associated with a high incidence of Cormack-Lehane 3 or 4 grade, but not necessarily a failed intubation. When the obvious cases presented above are excluded, the tests or criteria should be used only as indicators. The challenge originates from the low incidence of failed tracheal intubation in the hands of experienced anesthesiologists. Interesting results were obtained in studies where radiological criteria were used, ${ }^{7,8}$ but this approach is not practical in routine clinical practice. In other studies, the use of ultrasonography has been suggested to anticipate the degree of airway difficulty, but it would be premature at this time to formulate recommendations about the use of this technology in airway management. ${ }^{9,10}$ Even calculating airway indices that incorporate many assessment criteria, such as those proposed by Wilson et al. ${ }^{11}$ and Arné et al., ${ }^{12}$ does not consistently ensure accurate evaluation of the risk of failed laryngoscopy.

Although the possibility to predict difficult intubation accurately has been questioned, examining the patient and evaluating accepted criteria remain useful, ${ }^{6}$ especially in situations where physical characteristics are unclear or where there is a history of difficult intubation, radiotherapy in the neck area, snoring, etc. Examining the upper airway might reveal anomalies that may not have been obvious at first sight but may have a major impact on the intubation technique (e.g., a restricted mouth opening). However, it is important to realize that, except in the most obvious cases, evaluating the probability of failed laryngoscopy is a 
Table 1 Examples of sensitivities and specificities reported for different criteria for the prediction of difficult direct laryngoscopy

\begin{tabular}{|c|c|c|c|}
\hline Study & Criterion & Sensitivity (\%) & Specificity $(\%)$ \\
\hline \multicolumn{4}{|l|}{ Simple criteria } \\
\hline Tse $e^{t} a .^{23}$ & Mallampati class $\geq 3$ & 66 & 65 \\
\hline El-Ganzouri et al. ${ }^{24}$ & Mallampati class $\geq 3$ & 44.7 & 89 \\
\hline Shiga et $a l_{.}^{25 a}$ & Mallampati class $\geq 3$ & 49 & 86 \\
\hline Krobbuaban et al. ${ }^{26}$ & Mallampati class $\geq 3$ & 70 & 60 \\
\hline Tse et $_{a l .}{ }^{23}$ & Thyromental distance $\leq 7 \mathrm{~cm}$ & 32 & 80 \\
\hline El-Ganzouri et al. ${ }^{24}$ & Thyromental distance $<6 \mathrm{~cm}$ & 7 & 99.2 \\
\hline Shiga et $a ._{.}^{25 a}$ & Thyromental distance $<4$ to $<7 \mathrm{~cm}$ & 20 & 94 \\
\hline Krobbuaban et al. ${ }^{26}$ & Thyromental distance $\leq 6.5 \mathrm{~cm}$ & 52 & 71 \\
\hline Tse et $\mathrm{l}_{.}{ }^{23}$ & Neck extension $\leq 80^{\circ}$ & 10 & 93 \\
\hline El-Ganzouri et al. ${ }^{24}$ & Neck extension $\leq 80^{\circ}$ & 10.4 & 98.4 \\
\hline Krobbuaban et al. ${ }^{26}$ & Neck extension $\leq 80^{\circ}$ & 13 & 93 \\
\hline El-Ganzouri et al. ${ }^{24}$ & Mouth opening $<4 \mathrm{~cm}$ & 26.3 & 94.8 \\
\hline Shiga et $a l .{ }^{25 a}$ & Mouth opening $<3.5 \mathrm{~cm}$ & 22 & 97 \\
\hline Krobbuaban et al. ${ }^{26}$ & Mouth opening $<3.5 \mathrm{~cm}$ & 39 & 69 \\
\hline El-Ganzouri et al. ${ }^{24}$ & Weight $>110 \mathrm{~kg}$ & 11.1 & 94.3 \\
\hline Lundstrom et al. ${ }^{27}$ & Weight $>110 \mathrm{~kg}$ & 6 & 95 \\
\hline Huh et al. ${ }^{28}$ & Hyomental distance $>5.5 \mathrm{~cm}$ (neutral position) & 23 & 95 \\
\hline Huh et al. ${ }^{28}$ & Hyomental distance $\leq 5.3 \mathrm{~cm}$ (maximum extension) & 31 & 92 \\
\hline Shiga et $a l .{ }^{25 a}$ & Sternomental distance $<12.5$ to $\leq 13.5 \mathrm{~cm}$ & 62 & 82 \\
\hline Lundstrom et al. ${ }^{27}$ & $\mathrm{BMI}>35$ & 7 & 94 \\
\hline Khan et al. ${ }^{29}$ & Upper lip bite test $=3$ & 76.5 & 88.7 \\
\hline Eberhart et $a .^{30}$ & Upper lip bite test $=3$ & 28.2 & 92.5 \\
\hline El-Ganzouri et al. ${ }^{24}$ & History of difficult intubation & 4.5 & 99.8 \\
\hline \multicolumn{4}{|c|}{ More than one criterion, ratio, index } \\
\hline Tse et $\mathrm{l}_{.}{ }^{23}$ & Mallampati class $\geq 3+$ thyromental distance $\leq 7 \mathrm{~cm}$ & 21 & 92 \\
\hline Huh et al. ${ }^{28}$ & Ratio: hyomental distance in maximum extension/neutral position $<1.2$ & 88 & 60 \\
\hline Shiga et al. ${ }^{25 \mathrm{a}}$ & Mallampati class $\geq 3+$ BMI $>30$ & 74 & 74 \\
\hline Naguib et al. $^{31}$ & Wilson index & 40.2 & 92.8 \\
\hline Arné et al. ${ }^{12}$ & Arné index & 93 & 93 \\
\hline Naguib et al. ${ }^{31}$ & Arné index & 54.6 & 94.9 \\
\hline Naguib et al. ${ }^{31}$ & Naguib index & 81.4 & 72.2 \\
\hline
\end{tabular}

$B M I$ body mass index

${ }^{a}$ Results of a meta-analysis

difficult task that depends heavily on the experience of the anesthesiologist.

Ventilation with a supraglottic airway device

In addition to the traditional oropharyngeal or nasopharyngeal airways, a wide variety of new supraglottic devices for airway management and ventilation are currently available. In most anesthetized patients, the lungs are ventilated at some point during the perioperative period using a supraglottic device. Whether a laryngeal mask airway is used throughout the surgical procedure or an oropharyngeal airway is used to facilitate bag-mask ventilation prior to tracheal intubation, supraglottic devices play a key role in maintaining upper airway patency. It should be emphasized that ventilation can often be achieved in one way or another using supraglottic devices, even when direct laryngoscopy and tracheal intubation turn out to be impossible. ${ }^{13}$ Recognizing that failure to intubate the trachea following direct laryngoscopy is a rare occurrence, complete failure to ventilate using a face mask and an oropharyngeal airway is an even rarer occurrence. ${ }^{14}$ There are many published anecdotal cases where ventilation and oxygenation could be established with a laryngeal mask airway or another supraglottic device after repeated unsuccessful attempts at direct laryngoscopy. ${ }^{15-18}$ Although ventilation with supraglottic 
Table 2 Examples of the influence of certain characteristics on difficult mask ventilation
$B M I$ body mass index; $C I$ confidence interval

\begin{tabular}{|c|c|c|c|}
\hline Study & Criterion & Odds ratio & CI $95 \%$ \\
\hline \multirow[t]{5}{*}{ Langeron et al. ${ }^{32}$} & Beard & 3.18 & $1.39-7.27$ \\
\hline & $\mathrm{BMI}>26$ & 2.75 & $1.64-4.62$ \\
\hline & No teeth & 2.28 & $1.26-4.10$ \\
\hline & Age $>55$ yr & 2.26 & $1.34-3.81$ \\
\hline & Snoring & 1.84 & $1.09-3.10$ \\
\hline \multirow[t]{5}{*}{ Yildiz et $a l^{33}$} & Mallampati class 4 & 9.69 & $1.25-74.98$ \\
\hline & Male & 3.53 & $2.17-5.40$ \\
\hline & Snoring & 2.18 & $1.38-3.45$ \\
\hline & Elderly & 1.03 & $1.01-1.04$ \\
\hline & Obesity & 1.02 & $1.00-1.03$ \\
\hline \multirow[t]{5}{*}{ Kheterpal et al. ${ }^{14}$} & Neck changes due to radiotherapy & 7.1 & $2.1-24.4$ \\
\hline & Male & 3.3 & $1.8-6.3$ \\
\hline & Sleep apnea & 2.4 & $1.3-4.3$ \\
\hline & Mallampati class $\geq 3$ & 2.0 & $1.1-3.4$ \\
\hline & Beard & 1.9 & $1.1-3.3$ \\
\hline \multirow[t]{6}{*}{ Kheterpal et al. ${ }^{34}$} & $\mathrm{BMI}>30$ & & \\
\hline & Beard & 1 criterion 6.32 & \\
\hline & Mallampati class $\geq 3$ & 2 criteria 10.5 & \\
\hline & Age $\geq 57$ yr & 3 criteria 19.6 & \\
\hline & Limited mandibular protusion & 4 criteria 35.4 & \\
\hline & Snoring & & \\
\hline
\end{tabular}

devices is more often efficacious than direct laryngoscopy, criteria to predict success or failure are even less clear than for tracheal intubation.

A few studies have attempted to identify certain factors associated with difficult ventilation with a face mask (Table 2). A few of these criteria, such as limited mandibular protrusion, are also associated with difficult direct laryngoscopy. Other criteria, including being edentulous, make direct laryngoscopy easier. Criteria to predict failure to insert other supraglottic devices, such as the laryngeal mask airway, are even more poorly defined. While there are cases where direct laryngoscopy is impossible, there are also situations where a laryngeal mask airway cannot be used, e.g., patients with a very limited mouth opening. However, in contrast to tracheal intubation, which can only be either a success or a failure, supraglottic ventilation might be partially successful. Thus, it is unusual for such a technique to provide absolutely no ventilation and no oxygenation; however, if such a situation occurs and tracheal intubation cannot be performed rapidly, a surgical airway (tracheostomy or cricothyrotomy) must be obtained. In exceptional situations, extracorporeal circulation can be considered when such resources are immediately available. As is the case for direct laryngoscopy, criteria to anticipate difficult or ineffective supraglottic ventilation are poor predictors. When present, the criteria listed in Table 2 indicate that ventilation with face mask might be more difficult than usual, although it is rarely completely ineffective. The impact of those factors on the effectiveness of other supraglottic devices, such as the laryngeal mask airway, has not been studied systematically. However, it is encouraging to note that these devices have been used successfully in numerous instances traditionally associated with difficult ventilation, such as Cesarean delivery under general anesthesia. ${ }^{19}$

\section{A systematic approach to the anticipated difficult airway}

Use of guidelines

It is important to use a systematic approach and a welldefined plan when faced with a patient with a potentially difficult airway. Several specialty societies, such as the American Society of Anesthesiologists (ASA), have developed specific guidelines for this type of situation. The ASA algorithm ${ }^{2}$ covers a wider spectrum of circumstances than those addressed in this module, which is essentially restricted to cases where a possible difficult airway was identified before induction of anesthesia. It should be emphasized, however, that few recommendations have been validated rigorously. Most guidelines are derived from the experience of airway experts and analysis of the related literature, which consists of a limited number of randomized controlled trials and numerous case reports. Only a few relatively simple strategies have been evaluated 
formally, for instance, the sequential use of a bougie and an intubating laryngeal mask airway after unsuccessful direct laryngoscopy. ${ }^{20}$ It is virtually impossible for all anesthesiologists to have the same comfort zone, familiarity, and skill set with respect to all available airway devices. Thus, the clinician must take personal skill and experience into consideration when applying recommendations by experts and should consider asking for help from a colleague who has skills in the use of a technique indicated for a special situation. However, assistance from a colleague is no substitute for a systematic approach and good planning.

When a patient presents with foreseeable airway management problems, several questions should be asked to define the possible options. If local or regional anesthesia constitute reasonable choices for a surgical procedure in a patient with possible difficult airway management, it is often best to proceed that way. If it is necessary to administer a general anesthetic to a patient with a possible difficult airway, then one of the first questions to ask is whether it is best to perform tracheal intubation or can a supraglottic device be used for the duration of the procedure. Several supraglottic devices are designed for ventilation. Table 3 lists only some of them, as many new devices are commercialized constantly. While some devices are designed essentially to ventilate; others also allow the possibility to insert a tracheal tube. With the Fast$\operatorname{rach}^{\mathrm{TM}}$, it is possible to ventilate the patient's lungs, although this device was designed primarily to allow intubation. Other devices have specific features to avoid regurgitation of contents from the gastrointestinal tract. Several devices incorporate a drainage tube to evacuate or a reservoir to store regurgitated material, while others rely on esophageal obstruction.

If tracheal intubation is not necessary

The decision whether to intubate or to use a supraglottic device depends on several factors. At present there are no definite criteria establishing formal indications or contraindications for the use of such devices. For most clinicians, gastroesophageal reflux would be considered a contraindication regardless of the features of the supraglottic device employed. The anticipated duration of the surgical procedure, the type of surgery (abdominal, laparoscopic), the position of the patient during the operation (supine, prone, lateral), the surgical site (head and neck, thoracic), and certain patient characteristics, such as obesity, are all likely to influence the decision whether to use a supraglottic device. There are no set rules, and practices vary amongst anesthesiologists depending on their experience, familiarity with the type of device, and the medical culture in their hospital. When faced with a potential difficult airway, many practitioners systematically choose tracheal intubation instead of the insertion of supraglottic devices, because they are concerned that supraglottic devices might not provide adequate ventilation throughout surgery. It should be noted, however, that even if a supraglottic ventilation device is deemed inappropriate for a given surgical procedure, this does not mean that such a device cannot be part of airway management. As will be seen later, using such a device may, in fact, make tracheal intubation much easier in patients with a possible difficult airway.

Table 3 Examples of supraglottic devices for ventilation

\begin{tabular}{|c|c|}
\hline Device & Features \\
\hline Classic $^{\mathrm{TM}}$ Laryngeal Mask Airway & $\begin{array}{l}\text { Well known. A single lumen designed for ventilation, but insertion of a tracheal tube is } \\
\text { possible. Reusable }\end{array}$ \\
\hline Unique $^{\mathrm{TM}}$ Laryngeal Mask Airway & Similar to Classic ${ }^{\mathrm{TM}}$ Laryngeal Mask Airway, but single use only \\
\hline ProSeal $^{\mathrm{TM}}$ Laryngeal Mask Airway & $\begin{array}{l}\text { Two lumens, one for ventilation, the other towards the gastrointestinal tract to decrease the } \\
\text { risk of pulmonary aspiration. Insertion may be accomplished either with fingers or a rigid } \\
\text { device. Not designed for insertion of a tracheal tube }\end{array}$ \\
\hline Supreme ${ }^{\mathrm{TM}}$ Laryngeal Mask Airway & Two lumens like the ProSeal ${ }^{\mathrm{TM}}$, and more rigid. Single use \\
\hline Fastrach $^{\mathrm{TM}}$ Intubating Laryngeal Mask Airway & Rigid device that may be used to ventilate, but designed primarily to insert a tracheal tube \\
\hline King $\mathrm{LT}^{\mathrm{TM}}$ Laryngeal Tube & A single lumen. Two cuffs: one in the oropharynx, the other to block the esophagus \\
\hline King LTS-D ${ }^{\mathrm{TM}}$ Laryngeal Tube & $\begin{array}{l}\text { Two lumens: one to ventilate, the other towards the gastrointestinal tract. Two cuffs as with } \\
\text { the King } \mathrm{LT}^{\mathrm{TM}} \text {. A tube exchanger may be inserted }\end{array}$ \\
\hline SLIPA $^{\mathrm{TM}}$ & $\begin{array}{l}\text { A single lumen, but presence of a reservoir to capture regurgitated material. No inflatable } \\
\text { cuff. Single use }\end{array}$ \\
\hline $\mathrm{I}-\mathrm{Gel}^{\mathrm{TM}}$ & $\begin{array}{l}\text { Two lumens: one to ventilate, the other towards the gastrointestinal tract. No inflatable cuff. } \\
\text { Insertion of a tracheal tube is possible. Single use }\end{array}$ \\
\hline Cobra PLA ${ }^{\mathrm{TM}}$ & $\begin{array}{l}\text { Single lumen designed for ventilation, but insertion of a tracheal tube is possible. Single } \\
\text { use }\end{array}$ \\
\hline Combitube ${ }^{\mathrm{TM}}$ & $\begin{array}{l}\text { Large device. Two lumens, one for ventilation, one for the esophagus. Two cuffs. Used } \\
\text { mainly in prehospital care. Single use }\end{array}$ \\
\hline
\end{tabular}




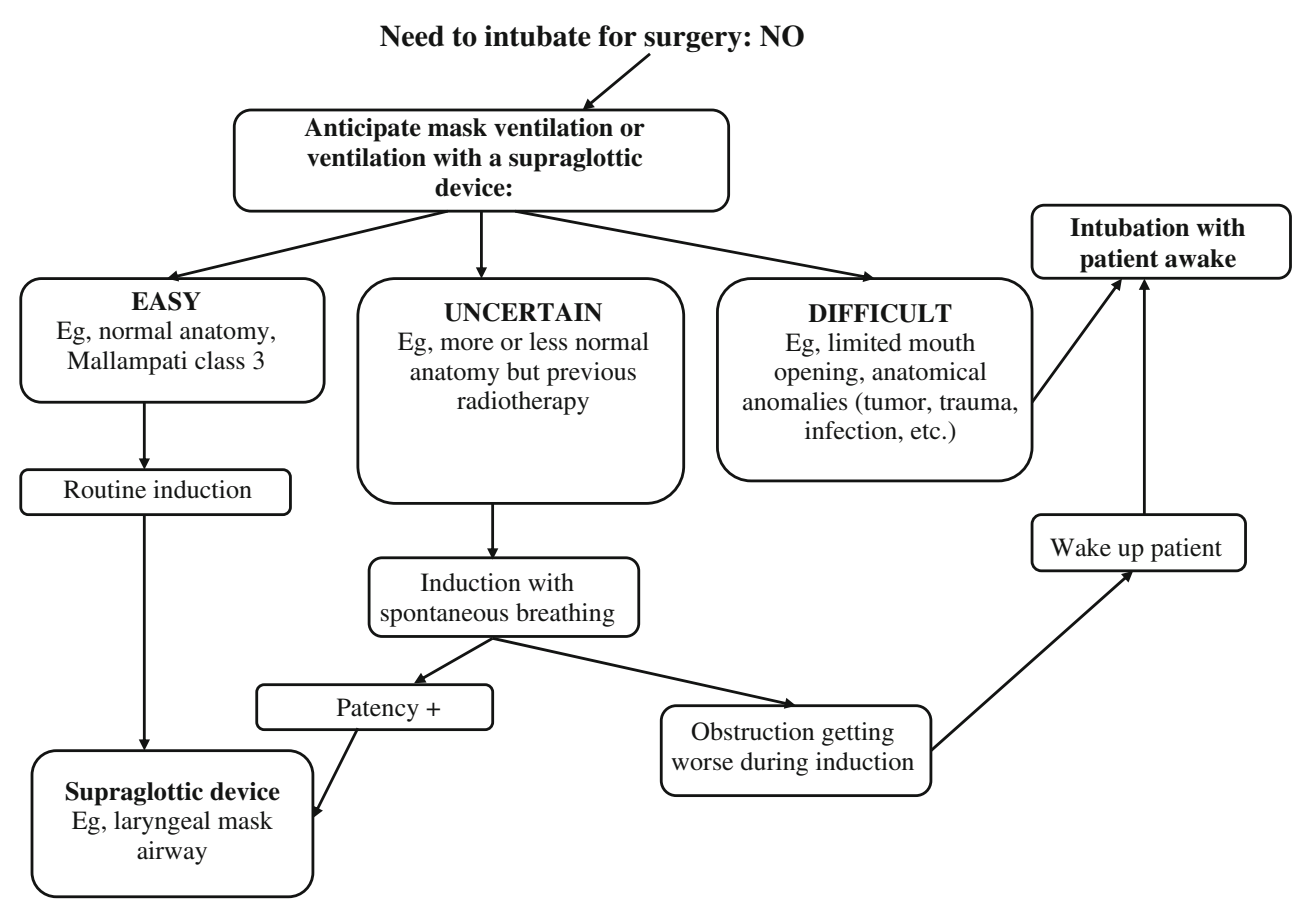

Fig. 1 Need to intubate for surgery: NO

Therefore, if tracheal intubation is deemed unnecessary for a given procedure, the anesthesiologist should evaluate the probability that a supraglottic device might allow adequate ventilation in a patient with possible difficult airway management (Fig. 1). In other words, would a laryngeal mask airway or another similar device or, for short procedures, an oropharyngeal airway or a face mask, be likely to allow proper ventilation and oxygenation? For most patients with possible difficult airway management, the answer to this question is either "yes" or "no". At this stage, the experience and familiarity of the anesthesiologist with this type of device play an important role. Still, there are cases where the anesthesiologist would not be able to provide a clear answer regarding the anticipated effectiveness of a supraglottic device. If the clinician involved determines that the airway problems (identified when the airway was evaluated) are unlikely to alter the effectiveness of a laryngeal mask airway or a similar device, i.e., if the answer to the question regarding the anticipated effectiveness of supraglottic ventilation is "yes", we propose that the anesthesiologist can proceed with a routine induction and insert the chosen device. Patients with a moderately limited mouth opening or a Mallampati class assessed at 3 without any other special anatomical anomaly usually fall under that category. Direct laryngoscopy and intubation could potentially be difficult in these patients, yet they show no appearance of special difficulties for the insertion of a $\mathrm{LMA}^{\circledR}$ or similar device.

However, if the anesthesiologist's airway assessment indicates that a supraglottic airway will probably be unsuccessful, i.e., if the answer to the question, "Can we anticipate successful ventilation with a laryngeal mask airway or similar device?" is "no", then it is preferable to proceed to intubate the patient awake using a fibrescope or another method, even if intubation is not required for the planned surgical procedure. Patients with anomalies interfering with upper airway anatomy, such as tumors or abscesses, often fall within that category. This does not mean that using a laryngeal mask airway or similar device is inevitably ineffective in these patients, since many case reports show the usefulness of these devices in emergency situations, even when used with pathological features leading to significant changes in the upper airway. ${ }^{21,22}$

There is a category of patients for whom the anesthesiologist remains uncertain regarding the potential success of supraglottic ventilation. There is a reason to believe that supraglottic ventilation is likely to work for these patients; however, they have anomalies that leave room for doubt. Patients with apparently normal airway anatomy, except for signs of previous radiotherapy, may sometimes belong to that group. In these cases, it is possible to proceed with a sevoflurane inhalation induction to maintain spontaneous ventilation, then to insert an oropharyngeal airway, then to switch to a laryngeal mask airway or similar device with the patient spontaneously breathing, and finally to establish that manual ventilation through the chosen device is adequate. If adequate manual ventilation is achieved, then the clinician has confirmed that supraglottic ventilation works well, and the answer to the question regarding the effectiveness of 
ventilation is "yes". However, if airway patency gets progressively worse during the inhalation induction while the patient is breathing spontaneously and the anesthesiologist is unsure about the success of supraglottic ventilation, it is appropriate to allow the patient to awaken and then to proceed with intubation of the awake patient. Again, we emphasize that both personal experience in airway assessment and practical knowledge of supraglottic airway devices greatly influence the anesthesiologist's decision to allocate a patient into one category or the other. For example, a less experienced clinician with the use of supraglottic devices or with inhalation induction in adults will be less likely to use this technique and will probably choose intubation of the awake patient.

When tracheal intubation is the preferred course of action

If it is believed that tracheal intubation with direct laryngoscopy is potentially difficult; a supraglottic device may play a significant role to facilitate endotracheal tube insertion. Once the decision is made to perform the surgical procedure with a tracheal tube in place, the first question to ask is whether the patient presents a significant risk of aspiration of gastric contents (Fig. 2). When significant problems with airway management and a risk of aspiration are anticipated, it is preferable to intubate the trachea while the patient is awake. If there is no significant risk of aspiration, then the probability that a supraglottic device will provide adequate ventilation should be evaluated. If the answer to that question is "yes", it is possible to proceed with a routine induction knowing that a laryngeal mask airway or similar device can be used as backup to oxygenate and ventilate adequately. Depending on the choice of supraglottic device, the clinician could withdraw the device and proceed with an appropriate intubation technique (Table 4) or choose a device that can be used to facilitate the insertion of a tracheal tube (e.g., intubating laryngeal mask, I-Gel ${ }^{\mathrm{TM}}$ ). Tracheal intubation can be achieved by combining different techniques. For example, it is appropriate to use a regular laryngeal mask airway and then to insert a tracheal tube under flexible bronchoscope guidance. The Fastrach ${ }^{\mathrm{TM}}$ can also be used with a tracheal tube over a Trachlight ${ }^{\mathrm{TM}}$-type lighted stylet, which is made less rigid by removing its stiff wire. The videolaryngoscope is another option. If it becomes difficult to reach the glottic opening with the recommended stylet, a flexible bronchoscope held by a second operator can be used instead of the stylet, while its movement is tracked on the videolaryngoscope screen. To a large extent, the choice of intubation technique should be dictated by the one with which the anesthesiologist is most familiar. Should failure to intubate occur, defaulting to supraglottic ventilation allows avoidance of hypoxia and hypoventilation irrespective of the final choice of intubation technique. A cautionary word with this approach is avoiding injury to the airway by traumatic or repeated attempts that could compromise return to effective supraglottic ventilation. If the clinician is unable to complete tracheal intubation with the techniques available, the best course of action is to

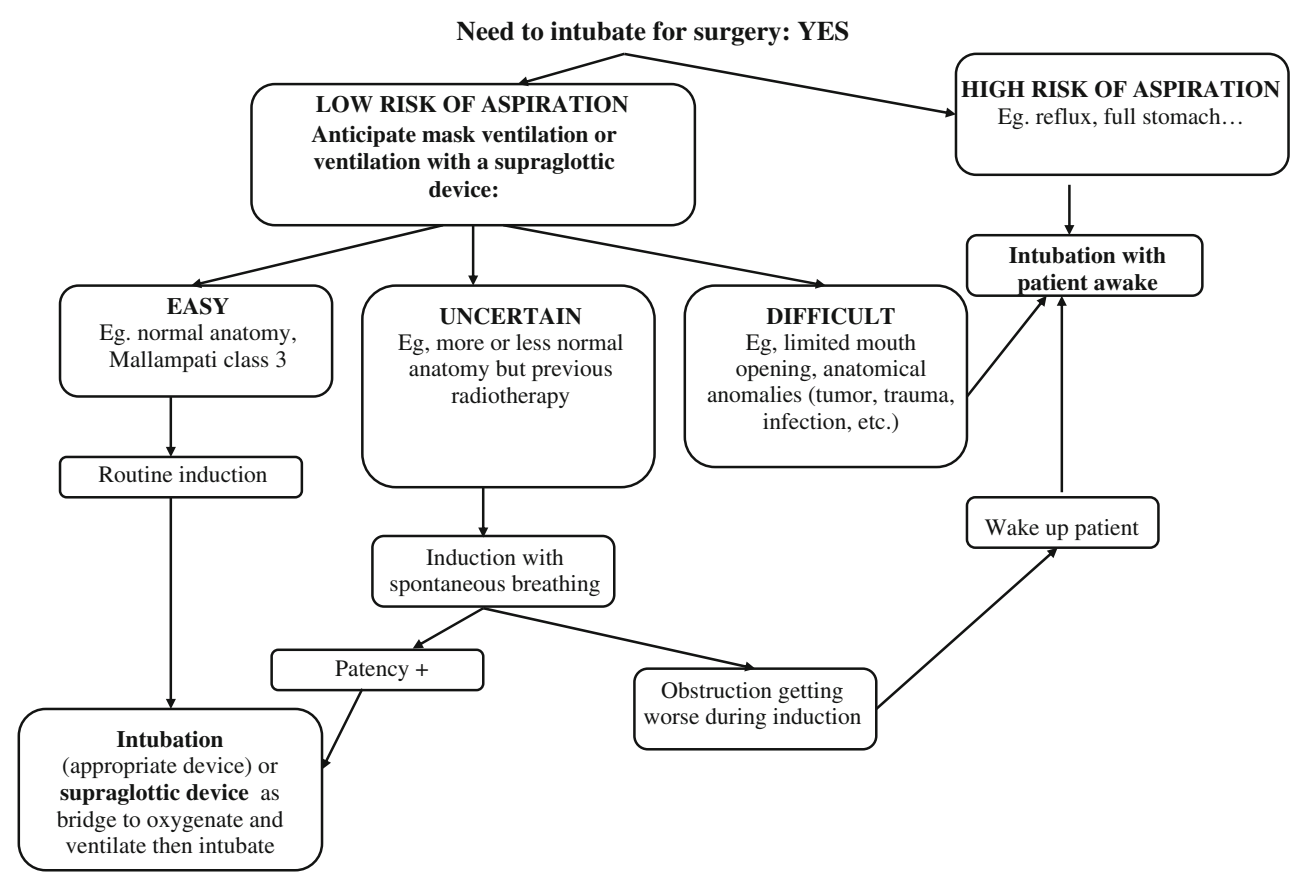

Fig. 2 Need to intubate for surgery: YES 
Table 4 Examples of devices designed to facilitate tracheal intubation

\begin{tabular}{|c|c|}
\hline Device & Characteristics \\
\hline Flexible bonchoscope & $\begin{array}{l}\text { Used commonly in the awake patient. Useful when major airway anomalies are present. } \\
\text { Less useful with copious amounts of blood and secretions }\end{array}$ \\
\hline Trachlight $^{\mathrm{TM}}$ & $\begin{array}{l}\text { The principle is transillumination. May be used in an awake or anesthetized patient. } \\
\text { May be more difficult to use in obese patients. Nasal use if rigid wire is removed }\end{array}$ \\
\hline Fastrach $^{\mathrm{TM}}$ Intubating Laryngeal Mask Airway & $\begin{array}{l}\text { Rigid device that may be used to ventilate, but designed primarily to insert a tracheal } \\
\text { tube }\end{array}$ \\
\hline Glidescope $^{\mathrm{TM}}$ & $\begin{array}{l}\text { Videolaryngoscope. Easy to use if familiar with direct laryngoscopy. A stylet is usually } \\
\text { necessary }\end{array}$ \\
\hline McGrath $^{\mathrm{TM}}$ Laryngoscope & $\begin{array}{l}\text { Videolaryngoscope. Easy to use if familiar with direct laryngoscopy. A stylet is usually } \\
\text { necessary. The blade can be adjusted }\end{array}$ \\
\hline Bonfils ${ }^{\mathrm{TM}}$ & Has some of the features of a rigid stylet, but provides a view similar to a bronchoscope \\
\hline Airtraq $^{\mathrm{TM}}$ & Rigid laryngoscope with a video screen (optional) and lumen to guide the tracheal tube \\
\hline Pentax-AWS ${ }^{\mathrm{TM}}$ & Rigid laryngoscope with a video screen and lumen to guide the tracheal tube \\
\hline Bullard ${ }^{\mathrm{TM}}$ Laryngoscope & Rigid laryngoscope with fiberscope and lumen to guide the tracheal tube \\
\hline
\end{tabular}

Several of these devices may be combined. For example, a Trachlight ${ }^{\mathrm{TM}}$, with the rigid wire removed, or a bronchoscope may be used with the Fastrach $^{\mathrm{TM}}$ or other supraglottic devices. A bronchoscope with the assistance of a second operator may serve as a stylet with the videolaryngoscope

abstain from further attempts and to allow the patient to awaken gently using a laryngeal mask airway or similar device rather than compromising the efficacy of the airway device by creating edema or injury to the upper airway.

If the patient is not at risk for aspiration, but it is perceived that supraglottic ventilation will not be effective, an awake intubation is recommended. If the anesthesiologist has doubts about the probable success of supraglottic ventilation, then an inhalation induction with sevoflurane with the patient breathing spontaneously can be considered. If the airway remains patent during induction, a device such as a laryngeal mask airway should be inserted, and the ability to manually ventilate the patient's lungs should be checked. If this procedure is successful, a suitable intubation technique may then be chosen, with the consideration that it is possible to default to supraglottic ventilation to ensure oxygenation and ventilation if intubation is unsuccessful. Again, untimely intubation attempts might compromise a return to supraglottic ventilation. If patency of the airway worsens during inhalation induction with spontaneous ventilation, the preferred course of action is to awaken the patient and to proceed with awake intubation. Again, the degree of the anesthesiologist's familiarity with ventilation devices and inhalation induction will influence to a large extent the decision when to proceed with one approach or the other. A lesser degree of familiarity will tip the balance towards awake tracheal intubation.

\section{Conclusion}

Irrespective of the approach taken, experience and proper planning play a key role in airway management. This is especially valid when traditional airway management with direct laryngoscopy is likely to be unsuccessful. Although recommended tools and criteria for an anticipated difficult airway using direct laryngoscopy or supraglottic ventilation are far from perfect, the experienced anesthesiologist should take them into account to devise a strategy centered on oxygenation and ventilation. We suggest a systematic approach that assesses the need for tracheal intubation and the probability of successful supraglottic ventilation. Key points in planning a safe strategy appropriate for possible difficulties in airway management include personal experience and familiarity with airway assessment, use of various intubation techniques and supraglottic ventilation, and inhalation induction with sevoflurane while spontaneous breathing is maintained.

\section{Module case scenario}

Your patient is a 57-yr-old male who is scheduled for cervical mediastinoscopy. He has a 2-cm lesion in the lower lobe of the left lung. His medical history is unremarkable, except for a 25 pack-yr smoking history and hypertension controlled by ramipril given once daily. The EKG, blood tests, and respiratory function tests are normal. The pulmonary lesion was identified as an incidental finding on chest X-ray when the patient was investigated prior to a laparoscopic cholecystectomy. When questioned about this operation that occurred several weeks previously, the patient appears anxious and responds immediately that he does not want to go through a similar experience. He mentions that the anesthesiologist awakened him immediately after he was put to sleep, because it 
was impossible to insert the airway tube, and he was told that he had to be intubated before he could be put to sleep again. What he went through (cough, agitation, pain) was so terrible he refuses any further surgery unless he is put to sleep before tracheal intubation. He further adds that he prefers to leave the hospital rather than go through the same ordeal that he suffered prior to his cholecystectomy.

\section{Instructions for completing the CPD module}

(1) Read the module and the references indicated in bold.

(2) Visit the Canadian Journal of Anesthesia website (http://www.springer.com/medicine/anesthesiology/ journal/12630), click "CPD online", and select the current module (Management of the anticipated difficult airway: a systematic approach).

(3) Answer the multiple choice questions regarding the case.

(4) After entering all of your answers, you will have access to an expert's explanation for each possible choice.

(5) Participants may claim up to $4 \mathrm{hr}$, for a total of eight credits, under Section 3 of the Continuing Professional Development (CPD) program of the Royal College of Physicians and Surgeons of Canada.

\section{Difficultés de prise en charge des voies aériennes: une approche systématique}

\author{
Résumé \\ Objectif $\mathrm{Ce}$ module de développement professionnel \\ continu $(D P C)$ vise à présenter une stratégie systématique \\ pour des problèmes anticipés de prise en charge des voies \\ aériennes. \\ Constatations principales L'accent doit être mis sur \\ l'oxygénation et la ventilation et non nécessairement sur \\ l'intubation trachéale. L'évaluation préopératoire des vo- \\ ies aériennes ne doit pas être dirigée uniquement sur les \\ difficultés possibles lors de la laryngoscopie directe, mais \\ aussi sur la probabilité d'établir une ventilation fructueuse \\ à l'aide d'instruments supraglottiques incluant la canule \\ oropharyngée ou le masque laryngé. Prédire avec certitude \\ les difficultés associées à la laryngoscopie directe ou à la \\ ventilation supraglottique demeure difficile et l'expérience \\ de l'anesthésiologiste joue alors un rôle important dans le \\ processus de décision. Lorsque des difficultés sont antici- \\ pées dans la prise en charge des voies aériennes, il \\ convient de se demander si l'intubation est nécessaire. Si \\ l'intubation trachéale n'est pas indispensable, l'anesthésio-
}

logiste doit alors estimer la probabilité qu'un instrument supraglottique s'avère efficace. Si cette probabilité est faible, il est alors indiqué de procéder à l'intubation du patient éveillé. Dans certains cas, l'induction au sévoflurane en ventilation spontanée peut être utilisée pour s'assurer de l'efficacité d'un instrument supraglottique. Si l'intubation est indiquée, celle-ci peut être facilitée par l'utilisation temporaire planifiée d'un outil supraglottique, qui peut souvent être mis à profit pour l'insertion du tube endotrachéal. Le choix d'un instrument supraglottique ou d'un outil d'intubation dépend essentiellement de l'expérience de l'anesthésiologiste.

Conclusion La gestion des voies aériennes doit faire l'objet d'une approche systématique centrée sur le maintien de l'oxygénation et la ventilation, particulièrement lorsque des difficultés sont prévues. Les outils supraglottiques peuvent jouer un rôle important dans cette approche, que ce soit pour la durée de la chirurgie ou comme aide à l'intubation.

\section{Objectifs de ce module de développement professionnel continu}

Après avoir lu et complété ce module, l'anesthésiologiste sera en mesure de:

1- Utiliser une approche systématique pour la prise en charge des voies aériennes;

2- Identifier certaines caractéristiques prédictives de difficultés lors de la prise en charge des voies aériennes;

3- Réaliser l'importance d'estimer les difficultés potentielles associées à la laryngoscopie directe et aussi à la ventilation avec un outil supraglottique;

4- Proposer des solutions pour la prise en charge des voies aériennes d'un patient présentant une histoire d'intubation difficile; et de

5- Définir le rôle de divers instruments disponibles pour la prise en charge des voies aériennes.

Des difficultés de prise en charge des voies aériennes peuvent survenir de façon inattendue. Toutefois, ce module de développement professionnel continu (DPC) porte principalement sur la prise en charge des voies aériennes chez des patients adultes pour lesquels des difficultés peuvent être anticipées. Bien que certains des principes exprimés ici puissent s'appliquer aux situations dans lesquelles les difficultés reliées à l'oxygénation, à la ventilation ou à l'intubation apparaissent de manière inattendue, le lecteur trouvera une discussion plus complète de ce problème dans d'autres articles ou monographies.

Plusieurs travaux relatifs à la prise en charge des voies aériennes de l'adulte ont pour thème central l'intubation trachéale. L'utilisation de la laryngoscopie directe afin 
d'insérer une sonde dans la trachée est l'un des éléments centraux de la pratique de l'anesthésie et constitue une habileté que tout anesthésiologiste acquiert tôt dans sa formation. Ainsi, plusieurs auteurs considèrent toujours l'intubation trachéale par laryngoscopie directe comme l'étalon auquel doivent être comparées toutes les techniques de prise en charge des voies aériennes. Il faut cependant réaliser qu'il existe maintenant plusieurs techniques qui permettent de s'assurer d'un contrôle adéquat des voies aériennes, et ce, sans le recours à la laryngoscopie directe ou à l'insertion d'une sonde trachéale. L'important n'est pas nécessairement d'arriver à intuber, mais plutôt de s'assurer que la ventilation et l'oxygénation soient toujours maintenues, et ce, pendant toute la durée du processus menant au contrôle des voies aériennes. En tant que spécialistes des voies aériennes, les anesthésiologistes ont maintenant à leur disposition une panoplie d'instruments destinés à faciliter l'oxygénation et la ventilation du patient, soit parce qu'ils sont conçus spécifiquement à cette fin (masque laryngé, tube laryngé...), soit parce qu'ils sont en mesure de faciliter l'intubation trachéale (laryngoscopes spéciaux, tige lumineuse, vidéolaryngoscope, bronchoscope flexible...).

L'information contenue dans ce module ne vise pas à se substituer aux recommandations déjà émises des groupes d'experts. ${ }^{1,2}$ Ce qui est proposé ici est une approche systématique destinée à la prise en charge planifiée du contrôle des voies aériennes de l'adulte, généralement dans le contexte périopératoire.

\section{L’évaluation des voies aériennes}

\section{La laryngoscopie directe}

La grande majorité des articles publiés traitant de l'évaluation des voies aériennes supérieures sont consacrés à l'identification de critères prédictifs visant à repérer les patients pour lesquels l'intubation orotrachéale par laryngoscopie directe est susceptible de poser problème. Néanmoins, certains auteurs ont aussi tenté d'identifier les obstacles à l'utilisation d'autres techniques d'intubation, qu'il s'agisse de la tige lumineuse, ${ }^{3}$ du masque laryngé d'intubation Fastrach ${ }^{\text {TM4 }}$ ou de la vidéolaryngoscopie. ${ }^{5}$ Ces articles sont cependant peu nombreux et il faut plutôt se résigner à recenser les cas rapportés afin de tenter de définir ou d'évaluer les avantages et limites de ces outils. Quoi qu'il en soit, tenter de prédire les difficultés reliées à l'intubation orotrachéale par laryngoscopie directe n'est pas toujours une tâche facile. ${ }^{6}$ Dans certains cas, les obstacles sont évidents, par exemple celui du malade présentant une volumineuse tumeur ou un abcès occupant l'oropharynx, ou encore celui dont les mâchoires sont fixées chirurgicalement à la suite d'une fracture. Il existe par ailleurs une majorité de patients pour lesquels même un examen sommaire (ouverture de bouche et extension cervicale) permet à l'anesthésiologiste expérimenté d'anticiper une technique d'intubation par laryngoscopie directe sans problème. On retrouve cependant une proportion de patients pour lesquels le clinicien souhaiterait disposer d'outils permettant de prédire avec précision le degré de difficulté anticipé pour la réalisation d'une laryngoscopie directe et d'une intubation fructueuse.

Plusieurs auteurs ont identifié des caractéristiques et proposé des techniques d'évaluation visant à identifier les patients chez qui l'intubation trachéale par laryngoscopie directe risque de s'avérer inefficace (Tableau 1). Parmi ces caractéristiques, on retient notamment l'obésité, une distance thyromentonnière courte, la classe de Mallampati, la mesure de la mobilité cervicale, l'ouverture de bouche ou la distance interincisive. Plus récemment, l'évaluation détaillée de la protrusion ou de la subluxation volontaire de la mandibule, ainsi que la distance hyomentonnière, se sont ajoutées à la liste. Certains de ces facteurs ou mesures évaluent des aspects différents, mais qui sont interreliés, par exemple l'indice de masse corporelle (IMC) et le poids. D'autres facteurs procurent une information unique, comme la protrusion mandibulaire, puisqu'elle est sollicitée de manière parfois musclée dans les cas de laryngoscopie directe difficile. Il faut cependant constater que la spécificité et la sensibilité des divers critères proposés ne permettent souvent d'obtenir qu'un estimé plutôt imprécis du degré de difficulté anticipé, particulièrement dans les cas litigieux. Très peu de patients, parmi les participants aux études visant à identifier les critères associés à la laryngoscopie directe difficile, ont connu un échec d'intubation par cette même laryngoscopie. Si un critère donné présente une spécificité élevée, cela signifie que sa présence permet d'anticiper une laryngoscopie dont le grade Cormack-Lehane est de 3 ou 4, mais rarement un échec d'intubation. Si l'on exclut les cas les plus évidents dont il a été question précédemment, l'information fournie par ces tests ou critères ne peut souvent être utilisée qu'à titre indicatif. Le problème émane du fait que, bien que l'incidence rapportée soit variable, la laryngoscopie infructueuse demeure un événement rare entre les mains d'anesthésiologistes expérimentés. Certains auteurs ont obtenu des résultats intéressants en ayant recours à des critères radiologiques, ${ }^{7,8}$ mais cette démarche demeure peu pratique dans le contexte clinique courant. D'autres auteurs ont suggéré l'utilisation de l'échographie afin d'anticiper le degré difficulté dans la prise en charge des voies aériennes, il est cependant trop tôt pour en déterminer l'intérêt. ${ }^{9,10}$ Même la confection d'indices comme ceux suggérés par Wilson ${ }^{11}$ ou Arné ${ }^{12}$ et incorporant plus d'un critère ne permet pas d'obtenir une estimation précise du risque de laryngoscopie infructueuse. 
Tableau 1 Exemples de sensibilité et spécificité observées pour divers critères visant à prédire la laryngoscopie directe difficile

\begin{tabular}{|c|c|c|c|}
\hline Auteur & Critère & Sensibilité \% & Spécificité \% \\
\hline \multicolumn{4}{|l|}{ Critères simples } \\
\hline Tse et coll. ${ }^{23}$ & Classe Mallampati $\geq 3$ & 66 & 65 \\
\hline el-Ganzouri et coll. ${ }^{24}$ & $"$ & 44,7 & 89 \\
\hline Shiga et coll. ${ }^{25 *}$ & $"$ & 49 & 86 \\
\hline Krobbuaban et coll. ${ }^{26}$ & $"$ & 70 & 60 \\
\hline Tse et coll. ${ }^{23}$ & Distance thyromentonnière $\leq 7 \mathrm{~cm}$ & 32 & 80 \\
\hline el-Ganzouri et coll. ${ }^{24}$ & Distance thyromentonnière $<6 \mathrm{~cm}$ & 7 & 99,2 \\
\hline Shiga et coll. ${ }^{25 *}$ & Distance thyromentonnière $<4$ à $<7 \mathrm{~cm}$ & 20 & 94 \\
\hline Krobbuaban et coll. ${ }^{26}$ & Distance thyromentonnière $\leq 6.5 \mathrm{~cm}$ & 52 & 71 \\
\hline Tse et coll. ${ }^{23}$ & Extension cervicale $\leq 80^{\circ}$ & 10 & 93 \\
\hline el-Ganzouri et coll. ${ }^{24}$ & 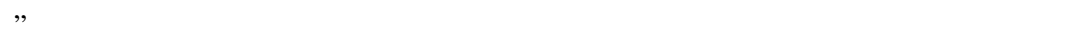 & 10,4 & 98,4 \\
\hline Krobbuaban et coll. ${ }^{26}$ & $"$ & 13 & 93 \\
\hline el-Ganzouri et coll. ${ }^{24}$ & Ouverture de bouche $<4 \mathrm{~cm}$ & 26,3 & 94,8 \\
\hline Shiga et coll. ${ }^{25 *}$ & Ouverture de bouche $<3,5 \mathrm{~cm}$ & 22 & 97 \\
\hline Krobbuaban et coll. ${ }^{26}$ & Ouverture de bouche $<3,5 \mathrm{~cm}$ & 39 & 69 \\
\hline el-Ganzouri et coll. ${ }^{24}$ & Poids $>110 \mathrm{~kg}$ & 11,1 & 94,3 \\
\hline Lundstrom et coll. ${ }^{27}$ & $"$ & 6 & 95 \\
\hline Huh et coll. ${ }^{28}$ & Distance hyomentionnière $>5,5 \mathrm{~cm}$ (position neutre) & 23 & 95 \\
\hline Huh et coll. ${ }^{28}$ & Distance hyomentionnière $\leq 5,3 \mathrm{~cm}$ (position extension maximale) & 31 & 92 \\
\hline Shiga et coll. ${ }^{25 *}$ & Distance sternomentonnière $<12,5$ à $\leq 13,5 \mathrm{~cm}$ & 62 & 82 \\
\hline Lundstrom et coll. $^{27}$ & $\mathrm{IMC}>35$ & 7 & 94 \\
\hline Khan et coll. ${ }^{29}$ & "Upper lip bite test" $=3$ & 76,5 & 88,7 \\
\hline Eberhart et coll. ${ }^{30}$ & "Upper lip bite test" = 3 & 28,2 & 92,5 \\
\hline el-Ganzouri et coll. ${ }^{24}$ & Histoire d'intubation difficile antérieure & 4,5 & 99,8 \\
\hline \multicolumn{4}{|c|}{ Plus d'un critère, ratios, indices } \\
\hline Tse et coll. ${ }^{23}$ & Classe de Mallampati $\geq 3+$ distance thyromentonnière $\leq 7 \mathrm{~cm}$ & 21 & 92 \\
\hline Huh et coll. ${ }^{28}$ & Ratio: distance hyomentionnière en position extension maximale/position neutre $<1,2$ & 88 & 60 \\
\hline Shiga et coll. ${ }^{25 *}$ & Classe de Mallampati $\geq 3+$ IMC $>30$ & 74 & 74 \\
\hline Naguib et coll. ${ }^{31}$ & Indice de Wilson & 40,2 & 92,8 \\
\hline Arné et coll. ${ }^{12}$ & Indice d'Arné & 93 & 93 \\
\hline Naguib et coll. ${ }^{31}$ & Indice d'Arné & 54,6 & 94,9 \\
\hline Naguib et coll. ${ }^{31}$ & Indice de Naguib & 81,4 & 72,2 \\
\hline
\end{tabular}

* Résultats d'une méta-analyse

IMC: indice de masse corporelle

Même si la possibilité de prédire de manière efficace l'intubation difficile a été remise en question, l'examen du patient et la recherche des critères décrits demeure utile, ${ }^{6}$ en particulier dans les cas qui présentent des caractéristiques suscitant des interrogations, que celles-ci soient d'ordre physique ou historique (antécédents d'intubation difficile, de radiothérapie de la sphère cervicale, de ronflements...). L'examen, même sommaire, des voies aériennes permet aussi de détecter des anomalies qui, sans être évidentes au premier coup d'oeil, peuvent avoir un impact majeur sur la technique d'intubation. C'est le cas, notamment, d'une ouverture de bouche très limitée. Il faut cependant réaliser que, toujours en excluant les cas de difficultés évidentes, estimer la probabilité d'une laryngoscopie infructueuse est un exercice difficile dont les résultats dépendent, en grande partie, de l'expérience de l'anesthésiologiste.

La ventilation avec un outil supraglottique

En plus des traditionnelles canules oro- ou naso-pharyngées, il existe maintenant une kyrielle de nouveaux outils supraglottiques destinés au maintien des voies aériennes et à la ventilation. La ventilation à l'aide d'instruments supraglottiques est donc effectuée, pendant une période plus ou moins prolongée, pour la grande majorité des malades anesthésiés. Qu'il s'agisse de l'utilisation d'un masque laryngé pendant la durée entière de la chirurgie ou de 
l'utilisation d'un masque facial et d'une canule oropharyngée pendant quelques secondes avant de procéder à l'intubation orotrachéale, les outils de ventilation supraglottiques occupent une place centrale dans le maintien de la perméabilité des voies aériennes. Il convient aussi de souligner que, sous une forme ou une autre, la ventilation à l'aide d'instruments supraglottiques est souvent possible là où l'intubation trachéale par laryngoscopie directe s'avère impossible. ${ }^{13}$ En effet, même si les situations d'échec à l'intubation par la laryngoscopie directe sont rares, les cas où la ventilation à l'aide d'un masque et d'une canule oropharyngée est impossible le sont encore plus. ${ }^{14} \mathrm{La}$ littérature est aussi truffée de cas anecdotiques pour lesquels une ventilation et une oxygénation adéquates ont pu être établies à l'aide d'un masque laryngé ou d'un autre outil supraglottique, et ce, après des échecs répétés d'intubation par laryngoscopie directe. ${ }^{15-18}$ Néanmoins, même si la ventilation à l'aide d'outils supraglottiques est plus souvent efficace que la laryngoscopie directe, les critères permettant d'en anticiper le succès ou l'échec sont encore plus mal précisés que ceux associés à l'intubation.

Il existe toutefois quelques travaux qui ont permis d'identifier certains facteurs associés à une ventilation difficile au masque facial. (Tableau 2). Certains de ces critères, comme la protrusion mandibulaire limitée, sont aussi associés à la laryngoscopie directe difficile. D'autres, telle l'absence de dents, facilitent au contraire l'intubation orotrachéale. Quant aux critères qui permettraient d'anticiper les échecs lors de l'utilisation d'autres outils supraglottiques comme le masque laryngé, ils sont encore plus mal connus. Tout comme pour la laryngoscopie directe, il existe des situations qui ne permettent évidemment pas l'utilisation de masques laryngés, par exemple une ouverture de bouche impossible. Il faut cependant se souvenir que, contrairement à l'intubation trachéale qui réussit ou échoue, la ventilation supraglottique peut s'avérer un succès partiel. Il est donc rare qu'elle ne puisse procurer ni oxygénation, ni ventilation. Lorsqu'une telle situation se produit, et que l'intubation trachéale ne peut être effectuée rapidement, il est alors nécessaire de procéder au contrôle des voies aériennes de manière chirurgicale ou invasive par trachéotomie ou cricothyrotomie. De manière très exceptionnelle, le recours à la circulation extracorporelle peut même être envisagé si l'équipement et le personnel sont disponibles immédiatement. Tout comme c'est le cas pour la laryngoscopie directe, les critères suggérés afin de prédire une ventilation supraglottique difficile ou inefficace n'apportent souvent qu'une réponse incomplète. Lorsque présents, les éléments décrits dans le Tableau 2 suggèrent néanmoins l'éventualité d'une ventilation au masque plus difficile, bien qu'il soit rare que celle-ci s'avère totalement inefficace. Quant à l'impact de ces facteurs sur la performance d'autres outils supraglottiques tel le masque laryngé, il n'a pas fait l'objet d'études concluantes. L'utilisation fructueuse de ce type d'outil dans de nombreuses situations traditionnellement associées aux
Tableau 2 Exemples de l'influence de certaines caractéristiques sur la difficulté de ventilation au masque facial

IMC: indice de masse corporelle; IC: intervalle de confiance

\begin{tabular}{|c|c|c|c|}
\hline Auteur & Critère & Rapport de cotes & IC $95 \%$ \\
\hline \multirow[t]{5}{*}{ Langeron et coll. ${ }^{32}$} & Barbe & 3,18 & $1,39-7,27$ \\
\hline & $\mathrm{IMC}>26$ & 2,75 & $1,64-4,62$ \\
\hline & Édenté & 2,28 & $1,26-4,10$ \\
\hline & $\hat{\text { Age }}>55$ ans & 2,26 & $1,34-3,81$ \\
\hline & Ronflement & 1,84 & $1,09-3,10$ \\
\hline \multirow[t]{5}{*}{ Yildiz et coll. ${ }^{33}$} & Mallampati classe 4 & 9,69 & $1,25-74,98$ \\
\hline & Sexe masculin & 3,53 & $2,17-5,40$ \\
\hline & Ronflement & 2,18 & $1,38-3,45$ \\
\hline & Patients âgés & 1,03 & $1,01-1,04$ \\
\hline & Obésité & 1,02 & $1,00-1,03$ \\
\hline \multirow[t]{5}{*}{ Kheterpal et coll. ${ }^{14}$} & Changements dans le cou dus à la radiothérapie & 7,1 & $2,1-24,4$ \\
\hline & Sexe masculin & 3,3 & $1,8-6,3$ \\
\hline & Apnée du sommeil & 2,4 & $1,3-4,3$ \\
\hline & Classe Mallampati $\geq 3$ & 2,0 & $1,1-3,4$ \\
\hline & Barbe & 1,9 & $1,1-3,3$ \\
\hline \multirow[t]{6}{*}{ Kheterpal et coll. ${ }^{34}$} & $-\mathrm{IMC}>30$ & & \\
\hline & - Barbe & \multicolumn{2}{|l|}{1 critère 6,32} \\
\hline & - Classe Mallampati $\geq 3$ & \multicolumn{2}{|l|}{2 critères 10,5} \\
\hline & - Âge $\geq 57$ ans & \multicolumn{2}{|l|}{3 critères 19,6} \\
\hline & - Protusion mandibule limitée & \multirow{2}{*}{\multicolumn{2}{|c|}{4 critères 35,4}} \\
\hline & - Ronflement & & \\
\hline
\end{tabular}


difficultés ventilatoires, telle la césarienne sous anesthésie générale, est cependant encourageante. ${ }^{19}$

\section{Une approche systématique}

\section{Utilisation des directives}

Lorsque confronté au malade présentant des difficultés potentielles de prise en charge des voies aériennes, il est important d'avoir recours à une approche systématique et planifiée. Certains organismes, tel l'American Society of Anesthesiology (ASA), ont proposé des directives pour ce type de situation. L'algorithme proposé par $1^{\prime} \mathrm{ASA}^{2} \mathrm{~s}^{\text {'in- }}$ téresse cependant à un éventail de situations plus large que celui couvert par ce module, lequel s'adresse essentiellement aux cas où les difficultés de prise en charge sont identifiées préalablement à l'induction de l'anesthésie générale. Il faut noter toutefois qu'en matière de prise en charge des voies aériennes, il n'existe que peu de recommandations qui ont fait l'objet d'une validation formelle. Les conduites proposées sont très largement le fruit de l'expérience des experts consultés et de l'analyse d'une littérature composée en grande partie de cas anecdotiques. Seules quelques stratégies relativement simples comme l'utilisation séquentielle d'une bougie et d'un masque laryngé d'intubation dans le cas où une tentative initiale d'intubation par laryngoscopie directe s'avère infructueuse ont fait l'objet d'une étude formelle. ${ }^{20}$ Les anesthésiologistes ne présentent pas tous des degrés de confort, de familiarité et d'habileté égaux avec l'ensemble des outils disponibles. Les recommandations d'experts doivent donc être utilisées par le clinicien à la lumière des compétences et de l'expérience qu'il possède. Au besoin, il est bien sûr souhaitable d'avoir recours à l'assistance d'un collègue, particulièrement si celui-ci possède les compétences nécessaires à l'utilisation d'une technique indiquée dans une situation précise. L'assistance ou la disponibilité d'un collègue ne doivent cependant pas faire oublier la nécessité de procéder de manière systématique et planifiée.

En présence d'un malade présentant des difficultés potentielles quant à la prise en charge des voies aériennes, quelques questions s'imposent afin de préciser les options envisageables. Si l'anesthésie locorégionale constitue une approche raisonnable dans le cas d'une chirurgie chez un malade présentant des difficultés anticipées au niveau de la prise en charge des voies aériennes, il est souvent préférable d'y recourir. S'il faut recourir obligatoirement à l'anesthésie générale chez un tel patient, l'une des premières questions à se poser est: Est-il préférable de procéder à une intubation trachéale ou peut-on utiliser un outil de ventilation supraglottique pour la durée de l'intervention? Il existe plusieurs instruments supraglottiques conçus pour la ventilation. Le Tableau 3 en présente une liste partielle, puisque de nouveaux instruments arrivent sur le marché de manière régulière. Certains instruments sont conçus essentiellement pour la ventilation, d'autres offrent accessoirement la possibilité d'y insérer une sonde trachéale. L'un d'entre eux, le Fastrach ${ }^{\mathrm{TM}}$, permet quant à lui de ventiler même s'il s'agit avant tout d'un instrument conçu pour l'intubation. Certains, parmi ces outils, présentent des caractéristiques qui sont destinées à éviter les régurgitations en provenance du tube digestif. Dans certains cas, ils sont munis d'un conduit visant l'évacuation ou d'un réservoir destiné au stockage du matériel régurgité alors que d'autres misent plutôt sur l'obstruction de l'oesophage.

\section{Si l'intubation trachéale n'est pas nécessaire}

La décision d'intuber, ou, alternativement, d'utiliser un instrument supraglottique, dépend de plusieurs facteurs. Il n'existe actuellement pas de critères définitifs qui permettent d'établir les indications ou contre-indications formelles à l'utilisation de tels outils. La présence de reflux gastro-oesophagien symptomatique ou d'un estomac plein est cependant considérée comme une contre-indication par la majorité des cliniciens, et ce, quelles que soient les caractéristiques de l'appareil supraglottique utilisé. La durée anticipée de la chirurgie, la nature de celle-ci (digestive, laparoscopique...), la position du patient durant l'intervention (dorsale, ventrale, latérale), le site chirurgical (tête et cou, thoracique...) et certaines caractéristiques propres au malade telles que l'obésité sont tous des éléments qui peuvent influencer la décision de procéder à l'opération avec un instrument supraglottique ou non. Il n'existe donc que peu de règles précises et les pratiques varient selon les anesthésiologistes, leur degré d'expérience, leur familiarité avec ce type d'instrument et la culture médicale du milieu hospitalier. Lorsque confrontés à des difficultés potentielles de gestion des voies aériennes, certains cliniciens optent automatiquement pour l'intubation trachéale plutôt que pour l'utilisation d'outils supraglottiques, au cas où ces derniers ne seraient pas en mesure d'assurer une ventilation satisfaisante pour la durée de la chirurgie. Notons cependant que, même s'il n'apparaît pas souhaitable de procéder à une intervention chirurgicale donnée avec un instrument de ventilation supraglottique, un tel outil peut quand même être mis à profit dans la prise en charge des voies aériennes. Comme nous le verrons plus bas, l'utilisation de ce type d'appareil peut grandement faciliter l'intubation trachéale chez les patients présentant des difficultés potentielles.

Donc, si l'intubation trachéale n'est pas jugée nécessaire pour une intervention particulière, l'anesthésiologiste doit alors se demander quelle est la probabilité qu'un appareil 
Tableau 3 Exemples d'instruments supraglottiques de ventilation

\begin{tabular}{|c|c|}
\hline Instrument & Caractéristiques \\
\hline Masque laryngé Classic ${ }^{\mathrm{TM}}$ & $\begin{array}{l}\text { Bien connu. Une seule lumière conçue pour la ventilation, mais possibilité d'y insérer un tube trachéal. } \\
\text { Stérilisable. }\end{array}$ \\
\hline Masque laryngé Unique ${ }^{\mathrm{TM}}$ & Analogue au masque laryngé Classic ${ }^{\mathrm{TM}}$ mais jetable. \\
\hline Masque laryngé ProSeal ${ }^{\mathrm{TM}}$ & $\begin{array}{l}\text { Deux lumières, l'une pour ventiler, l'autre vers le tube digestif, peut ainsi réduire le risque d'aspiration } \\
\text { pulmonaire. L'insertion peut être faite avec les doigts ou un instrument rigide. Non conçu pour y insérer un } \\
\text { tube trachéal. }\end{array}$ \\
\hline Masque laryngé Supreme ${ }^{\mathrm{TM}}$ & Possède deux lumières comme le ProSeal ${ }^{\mathrm{TM}}$, plus rigide que ce dernier. Jetable. \\
\hline $\begin{array}{l}\text { Masque laryngé d'intubation } \\
\text { Fastrach }^{\mathrm{TM}}\end{array}$ & $\begin{array}{l}\text { Instrument rigide qui peut être utilisé pour ventiler, mais qui est d'abord conçu pour y insérer un tube } \\
\text { endotrachéal. }\end{array}$ \\
\hline Tube laryngé King $\mathrm{LT}^{\mathrm{TM}}$ & Une seule lumière. Deux manchettes, l'une dans l'oropharynx, l'autre destinée à occlure l'oesophage. \\
\hline Tube laryngé King LTS-D ${ }^{\mathrm{TM}}$ & $\begin{array}{l}\text { Deux lumières, l'une pour ventiler, l'autre vers le tube digestif. Deux manchettes comme le King } \mathrm{LT}^{\mathrm{TM}} \text {. On } \\
\text { peut y insérer un échangeur de tube. }\end{array}$ \\
\hline SLIPA $^{\mathrm{TM}}$ & $\begin{array}{l}\text { Une seule lumière, mais présence d'un réservoir destiné à recevoir les régurgitations. Absence de manchette } \\
\text { gonflable. Jetable. }\end{array}$ \\
\hline $\mathrm{I}-\mathrm{Gel}^{\mathrm{TM}}$ & $\begin{array}{l}\text { Deux lumières, l'une pour ventiler, l'autre vers le tube digestif. Absence de manchette gonflable. Possibilité d'y } \\
\text { insérer un tube trachéal. Jetable. }\end{array}$ \\
\hline Cobra PLA ${ }^{\mathrm{TM}}$ & Une seule lumière conçue pour la ventilation, mais possibilité d'y insérer un tube trachéal. Jetable. \\
\hline Combitube ${ }^{\mathrm{TM}}$ & $\begin{array}{l}\text { Volumineux instrument. Deux lumières, l'une pour ventiler, l'autre digestive. Deux manchettes. Utilisé surtout } \\
\text { en médecine préhospitalière. Jetable. }\end{array}$ \\
\hline
\end{tabular}

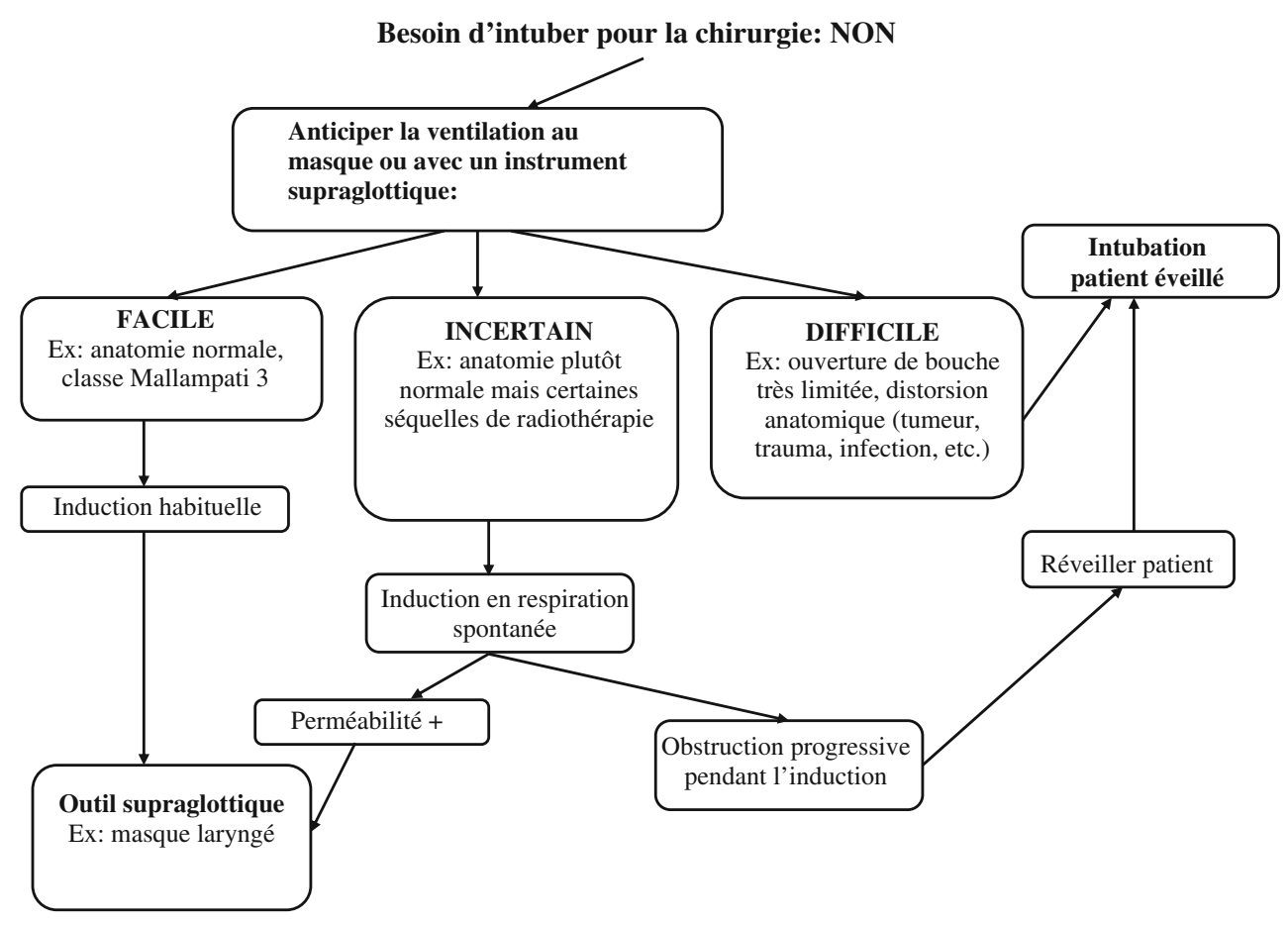

Fig. 1 Besoin d'intuber pour la chirurgie: NON

supraglottique puisse assurer une ventilation adéquate chez ce patient présentant des difficultés potentielles en regard de la prise en charge des voies aériennes (Fig. 1). En d'autres termes, est-ce que l'utilisation d'un masque laryngé ou de tout autre appareil du même type, ou encore, pour les interventions courtes, d'une canule oropharyngée et d'un masque facial est susceptible d'assurer une ventilation et une oxygénation adéquates? Pour la majorité des patients présentant des difficultés potentielles de gestion des voies aériennes, la réponse à cette question est OUI ou NON. Encore là, l'expérience de l'anesthésiologiste et sa familiarité avec ce type d'appareils jouent un rôle 
important. Il existe néanmoins des cas pour lesquels l'anesthésiologiste sera dans l'incapacité de se prononcer de manière ferme quant à l'efficacité anticipée d'un instrument supraglottique. $\mathrm{Si}$, de l'avis du clinicien impliqué, les difficultés identifiées lors de l'évaluation des voies aériennes ne sont pas de nature à entraver l'efficacité d'un masque laryngé ou d'un appareil analogue, donc si la réponse quant à l'efficacité anticipée de la ventilation supraglottique est OUI, nous considérons que l'anesthésiologiste peut procéder avec une induction conventionnelle et insérer l'instrument choisi. Les patients dont l'ouverture de bouche présente une limitation modérée ou encore dont la classe de Mallampati est jugée 3, mais sans anomalie anatomique particulière, s'inscrivent généralement dans cette catégorie. Il s'agit là de patients pour lesquels l'intubation par laryngoscopie directe pourrait paraître ardue, mais qui ne semblent pas présenter de difficultés significatives quant à l'insertion d'un masque laryngé ou de tout autre instrument semblable.

$\mathrm{Si}$, au contraire, l'évaluation des voies aériennes laisse croire à l'anesthésiologiste qu'il est probable qu'un instrument supraglottique s'avère inefficace, en d'autres mots, si la réponse à la question : « Peut-on anticiper qu'il sera possible de ventiler le patient avec un masque laryngé ou un appareil analogue? » est NON, il est alors conseillé de procéder avec l'intubation lorsque le malade est éveillé, par fibroscopie ou autrement, et ce, même si l'intubation n'est pas essentielle pour la chirurgie prévue. Les patients présentant des anomalies perturbant l'anatomie des voies aériennes (tumeurs, abcès...) entrent souvent dans cette catégorie. Cela ne signifie pas que l'utilisation d'un masque laryngé ou d'un instrument analogue s'avère obligatoirement inefficace chez de tels patients. En effet, plusieurs cas démontrent l'intérêt de ces outils dans un contexte d'urgence, et ce, même en présence de pathologies entraînant des déformations significatives des voies aériennes. ${ }^{21,22}$

Il existe des patients pour lesquels l'anesthésiologiste demeure INCERTAIN quant au succès potentiel de la ventilation supraglottique. Il s'agit là de malades pour lesquels le clinicien croit que la ventilation supraglottique est susceptible de fonctionner, mais qui présentent néanmoins des anomalies qui laissent planer un doute important. Les patients dont l'examen des voies aériennes paraît essentiellement normal, à l'exception de séquelles consécutives à la radiothérapie, peuvent parfois s'inscrire dans cette catégorie. Il est possible, dans de tels cas, de procéder avec une induction par inhalation au sévoflurane en conservant la respiration spontanée, d'insérer d'abord une canule oropharyngée, ensuite un masque laryngé ou un instrument analogue alors que le patient respire toujours spontanément et, finalement, de faire la démonstration que la ventilation manuelle au moyen de l'instrument choisi s'avère satisfaisante. Si c'est le cas, le clinicien confirme alors que la ventilation supraglottique est efficace et peut ainsi répondre OUI à la question visant l'efficacité de celleci. $\mathrm{Si}$, au contraire, au moment de l'induction par inhalation en respiration spontanée du patient chez qui l'anesthésiologiste a émis des réserves quant au succès de la ventilation supraglottique, la perméabilité des voies aériennes se détériore progressivement, il convient alors de réveiller le malade et de procéder ensuite avec l'intubation alors que ce dernier est éveillé. De nouveau, nous soulignons que l'expérience de l'anesthésiologiste en matière d'évaluation des voies aériennes et au niveau de sa familiarité avec les appareils de ventilation supraglottiques auront un impact certain sur sa décision d'assigner un malade dans l'une ou l'autre des catégories. Par exemple, le clinicien moins familier avec l'utilisation d'instruments supraglottiques ou encore avec l'induction de l'anesthésie par inhalation chez l'adulte sera moins enclin à procéder à cette dernière et optera plus volontiers pour l'intubation du patient éveillé.

\section{Lorsque l'intubation trachéale est jugée préférable}

Si l'on croit que l'intubation trachéale par laryngoscopie directe est susceptible de présenter des difficultés significatives, un instrument de ventilation supraglottique peut jouer un rôle significatif afin de faciliter l'introduction d'une sonde dans la trachée. La première question à se poser après avoir décidé de procéder à la chirurgie sous intubation trachéale est: « Le patient présente-t-il un risque significatif d'inhalation du contenu gastrique? » (Fig. 2) L'anticipation de difficultés significatives quant à la gestion des voies aériennes, combinée à un risque d'inhalation, milite en faveur d'une intubation chez le malade éveillé. Si le malade ne présente pas de risque particulier d'inhalation, il convient alors de s'interroger sur la probabilité de l'efficacité de la ventilation à l'aide d'instruments supraglottiques. Si l'on répond OUI à cette question, alors il est possible de procéder avec une induction conventionnelle sachant qu'au besoin, il est possible d'oxygéner et de ventiler correctement à l'aide d'un masque laryngé ou d'un instrument analogue. Dépendant de l'outil supraglottique choisi, ce dernier peut être retiré afin de céder la place à une technique d'intubation adaptée (Tableau 4), ou encore le clinicien peut opter pour un instrument capable d'être mis à contribution pour faciliter l'insertion de la sonde trachéale (masque laryngé d'intubation, I-Gel ${ }^{\mathrm{TM}}$, etc.). Il ne faut pas oublier que l'intubation trachéale d'un patient peut faire appel à plus d'une technique. Par exemple, il est tout à fait convenable d'utiliser un masque laryngé conventionnel et d'y insérer une sonde trachéale montée sur un bronchoscope flexible. Le Fastrach ${ }^{\mathrm{TM}}$ peut aussi être utilisé avec une sonde montée sur une tige lumineuse de type Trachlight ${ }^{\mathrm{TM}}$ rendue molle par le retrait de la broche. Le vidéolaryngoscope représente une alternative 


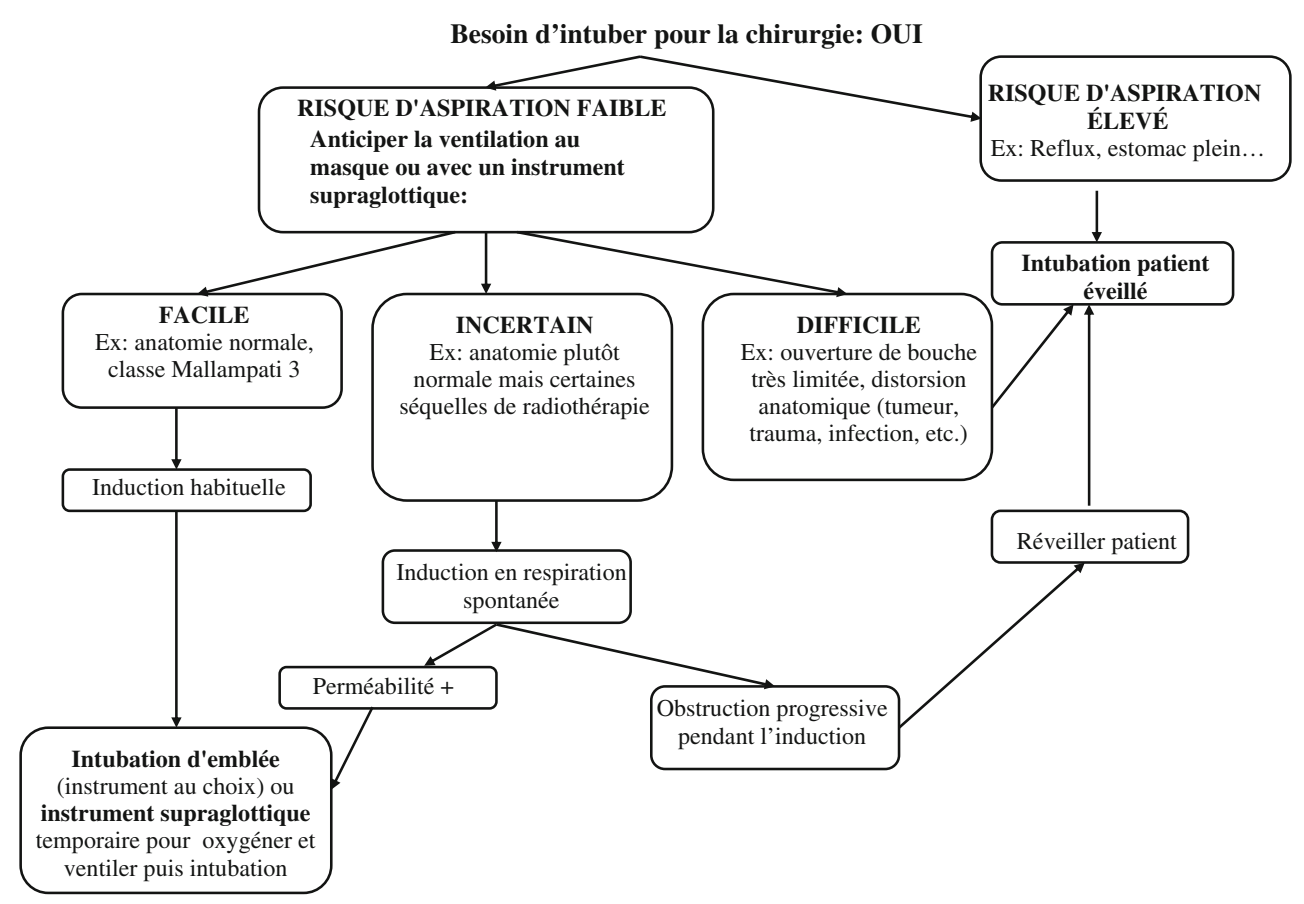

Fig. 2 Besoin d'intuber pour la chirurgie: OUI

Tableau 4 Exemples d'instruments destinés à faciliter l'intubation trachéale

\begin{tabular}{|c|c|}
\hline Instrument & Caractéristiques \\
\hline Bonchoscope flexible & $\begin{array}{l}\text { Fréquemment utilisé chez le patient éveillé. Utile dans les cas de déformations majeures des voies aériennes. } \\
\text { Moins utile si présence de sang ou de sécrétions abondantes. }\end{array}$ \\
\hline Trachlight $^{\mathrm{TM}}$ & $\begin{array}{l}\text { Procède par transillumination. Peut être utilisé chez le patient éveillé ou anesthésié. Peut être moins efficace } \\
\text { chez les patients obèses. Utilisation nasotrachéale possible en retirant la broche rigide. }\end{array}$ \\
\hline $\begin{array}{l}\text { Masque laryngé d'intubation } \\
\text { Fastrach }^{\mathrm{TM}}\end{array}$ & $\begin{array}{l}\text { Instrument rigide qui peut être utilisé pour ventiler, mais qui est d'abord conçu pour y insérer une sonde } \\
\text { trachéale. }\end{array}$ \\
\hline Glidescope $^{\mathrm{TM}}$ & $\begin{array}{l}\text { Vidéolaryngoscope. Facile à utiliser si familier avec laryngoscopie directe. Nécessite généralement l'utilisation } \\
\text { d'un mandrin. }\end{array}$ \\
\hline Laryngoscope McGrath $^{\mathrm{TM}}$ & $\begin{array}{l}\text { Vidéolaryngoscope. Facile à utiliser si familier avec laryngoscopie directe. Nécessite généralement l'utilisation } \\
\text { d'un stylet. Possibilité d'ajustements de la lame. }\end{array}$ \\
\hline Bonfils $^{\mathrm{TM}}$ & $\begin{array}{l}\text { Possède certaines caractéristiques d'un stylet rigide, mais procure une vision semblable à celle d'un } \\
\text { bronchoscope. }\end{array}$ \\
\hline $\operatorname{Airtraq}^{\mathrm{TM}}$ & Laryngoscope rigide muni d'un écran vidéo (optionnel) et d'un conduit destiné à diriger le tube trachéal. \\
\hline Pentax-AWS ${ }^{\mathrm{TM}}$ & Laryngoscope rigide muni d'un écran vidéo et d'un conduit destiné à diriger le tube trachéal. \\
\hline Laryngoscope Bullard ${ }^{\mathrm{TM}}$ & Laryngoscope rigide muni d'une fibre optique et d'un conduit avec stylet destiné à diriger le tube trachéal. \\
\hline
\end{tabular}

Plusieurs de ces instruments peuvent être combinés. Par exemple: le Tachlight ${ }^{\mathrm{TM}}$, dont on a retiré la broche rigide, ou le bronchoscope peuvent être utilisés en même temps que le Fastrach ${ }^{\mathrm{TM}}$ ou d'autres instruments supraglottiques. Le bronchoscope peut aussi, avec l'assistance d'un second opérateur, servir de stylet lors de la vidéolaryngoscopie

intéressante et, dans l'éventualité où l'orifice glottique est difficile à atteindre avec le stylet recommandé, ce dernier peut être remplacé par un bronchoscope flexible, tenu par un second opérateur, et dont la progression peut être suivie sur l'écran du vidéolaryngoscope. Le choix de la technique d'intubation sera dicté, en grande partie, par la familiarité de l'anesthésiologiste avec cette dernière. Peu importe la technique choisie, le retour à la ventilation supraglottique en cas d'échec permet à l'anesthésiologiste d'éviter l'hypoxie et l'hypoventilation. La contrainte principale reliée à cette approche est qu'il faut éviter d'endommager les voies aériennes par des tentatives d'intubation traumatisantes ou répétées à outrance, lesquelles pourraient compromettre l'efficacité du retour à la ventilation supraglottique. Dans l'éventualité où le clinicien s'avère incapable de procéder à l'intubation endotrachéale avec les 
techniques dont il dispose, mieux vaut s'abstenir et réveiller calmement le malade en utilisant un masque laryngé ou un instrument similaire plutôt que de compromettre l'efficacité de celui-ci en créant un oedème ou des lésions au niveau des voies aériennes supérieures.

Dans le cas d'un malade ne présentant pas de risque d'inhalation particulier mais pour lequel on répond NON au moment d'anticiper la possibilité d'une ventilation supraglottique efficace, on suggère alors de procéder avec l'intubation du patient éveillé. Si l'anesthésiologiste responsable entretient un doute quant à l'efficacité de la ventilation supraglottique et qu'il se dit donc INCERTAIN, il peut alors envisager de procéder avec une induction par inhalation en respiration spontanée à l'aide de sévoflurane. Dans l'éventualité où les voies aériennes demeurent perméables pendant l'induction, un instrument de type masque laryngé peut alors être inséré et on peut ensuite vérifier qu'il permet la ventilation manuelle. Si c'est le cas, l'anesthésiologiste peut alors utiliser la technique d'intubation qu'il juge appropriée, sachant que si celle-ci s'avère infructueuse, il peut compter sur le retour à l'usage de la ventilation supraglottique pour assurer l'oxygénation et la ventilation. De nouveau, il faut se souvenir que des tentatives d'intubation intempestives pourraient alors compromettre le retour à la ventilation supraglottique. Si, pendant l'induction par inhalation en respiration spontanée, la perméabilité des voies aériennes se détériore progressivement, il convient alors de réveiller le malade et de procéder à l'intubation de ce dernier éveillé. Encore là, le degré de familiarité de l'anesthésiologiste avec les instruments de ventilation supraglottiques ou l'induction par inhalation jouera un rôle prépondérant au moment d'opter pour une approche particulière. Moins un anesthésiologiste est familier avec ces techniques, plus il sera enclin à procéder directement à l'intubation du malade éveillé.

\section{Conclusion}

Quelle que soit l'approche adoptée, l'expérience et la planification jouent un rôle clé dans la gestion des voies aériennes. Ceci est particulièrement vrai lorsqu'une prise en charge conventionnelle, par laryngoscopie directe, est susceptible de s'avérer infructueuse. Bien que les outils ou critères suggérés pour l'anticipation des difficultés associées à la laryngoscopie directe ou à la ventilation supraglottique demeurent imparfaits, l'anesthésiologiste d'expérience doit en tenir compte afin d'élaborer une stratégie centrée sur l'oxygénation et la ventilation. Nous suggérons l'adoption d'une approche systématique dans laquelle la pertinence de l'intubation endotrachéale et la probabilité d'une ventilation supraglottique efficace doivent être évaluées. L'expérience et la familiarité de l'anesthésiologiste avec l'évaluation des voies aériennes, l'utilisation des diverses techniques d'intubation et de ventilation supraglottique, ainsi qu'avec l'induction par inhalation en respiration spontanée à l'aide de sévoflurane, sont tous des éléments qui contribuent à l'élaboration d'une stratégie sécuritaire et adaptée à la prise en charge des voies aériennes qui présentent des difficultés potentielles.

\section{Cas clinique}

Vous devez procéder à l'anesthésie d'un patient de 57 ans pour une médiastinoscopie cervicale. Le patient présente une masse de $2 \mathrm{~cm}$ dans le lobe inférieur du poumon gauche. Son histoire médicale présente peu de particularités à l'exception d'un tabagisme de l'ordre de 25 paquetsannées et d'une hypertension artérielle actuellement contrôlée par la prise quotidienne de ramipril. L'électrocardiogramme, les examens sanguins et les tests de fonctions respiratoires sont normaux. La masse pulmonaire a été découverte de manière fortuite six semaines plus tôt dans le cadre d'une investigation préopératoire précédant la réalisation d'une cholécystectomie par voie laparoscopique. Lorsque questionné sur le déroulement de cette cholécystectomie que le patient a donc subie quelques semaines plus tôt, ce dernier vous apparaît agité et vous mentionne d'emblée qu'il ne veut plus revivre une expérience semblable. Il dit, en effet, qu'après avoir été endormi, l'anesthésiologiste l'a réveillé et lui a mentionné qu'il fallait l'intuber avant de l'endormir de nouveau puisque l'insertion de la sonde trachéale s'était avérée impossible. L'expérience qu'il décrit alors (toux, agitation, douleur) lui a déplu au point qu'il refuse toute autre intervention s'il n'est pas endormi préalablement à l'intubation. Il mentionne qu'il préfère quitter l'hôpital plutôt que de revivre une expérience semblable à celle endurée au moment de sa cholécystectomie.

\section{Directives pour compléter le module DPC}

(1) Lisez les références indiquées en gras.

(2) Consultez le site Internet du Journal canadien d'anesthésie (http://www.springer.com/medicine/anes thesiology/journal/12630), cliquez sur « DPC en ligne », et choisissez le module actuel (Difficultés de prise en charge des voies aériennes).

(3) Répondez aux questions à choix de réponses concernant le cas clinique.

(4) Après avoir saisi toutes vos réponses, vous aurez accès aux explications d'experts pour tous les choix possibles. 
(5) Les participants peuvent réclamer à un maximum de quatre heures de DPC pour un total de huit crédits sous la Section 3 du programme de DPC du Collège royal des médecins et chirurgiens du Canada.

Competing interests None declared.

\section{References}

(In order to complete the learning section of this CPD module and claim CPD credits, please read the two bolded references below prior to answering the MCQ questions [Afin de compléter ce module de DPC et d'obtenir les crédits, prière de lire les références en italique avant de répondre aux QCM]).

1. Heidegger T, Gerig HJ, Henderson JJ. Strategies and algorithms for management of the difficult airway. Best Pract Res Clin Anaesthesiol 2005; 19: 661-74.

2. American Society of Anesthesiologists Task Force on Management of the Difficult Airway. Practice guidelines for management of the difficult airway: an updated report by the American Society of Anesthesiologists Task Force on Management of the Difficult Airway. Anesthesiology 2003; 98: 1269-77.

3. Wong SY, Coskunfirat ND, Hee HI, Li JY, Chen C, Tseng CH. Factors influencing time of intubation with a lightwand device in patients without known airway abnormality. J Clin Anesth 2004; 16: $326-31$

4. Roblot C, Ferrandiere M, Bierlaire D, Fusciardi J, Mercier C, Laffon $M$. Impact of Cormack and Lehane's grade on intubating laryngeal mask airway Fastrach using: a study in gynaecological surgery (French). Ann Fr Anesth Reanim 2005; 24: 487-91.

5. Tremblay $M H$, Williams $S$, Robitaille A, Drolet P. Poor visualization during direct laryngoscopy and high upper lip bite test score are predictors of difficult intubation with the GlideScope videolaryngoscope. Anesth Analg 2008; 106: 1495-500.

6. Yentis SM. Predicting difficult intubation-worthwhile exercise or pointless ritual? Anaesthesia 2002; 57: 105-9.

7. Naguib M, Malabarey T, AlSatli RA, Al Damegh S, Samarkandi $A H$. Predictive models for difficult laryngoscopy and intubation. A clinical, radiologic and three-dimensional computer imaging study. Can J Anesth 1999; 4: 748-59.

8. Kamalipour H, Bagheri M, Kamali K, Taleie A, Yarmohammadi $H$. Lateral neck radiography for prediction of difficult orotracheal intubation. Eur J Anaesthesiol 2005; 22: 689-93.

9. Tsui BC, Hui CM. Sublingual airway ultrasound imaging. Can J Anesth 2008; 55: 790-1.

10. Tsui BC, Hui CM. Challenges in sublingual airway ultrasound interpretation. Can J Anesth 2009; 56: 393-4.

11. Wilson ME, Spiegelhalter D, Robertson JA, Lesser P. Predicting difficult intubation. Br J Anaesth 1988; 61: 211-6.

12. Arne J, Descoins P, Fusciardi J, Ingrand P, Ferrier B, Boudigues $D$, et al. Preoperative assessment for difficult intubation in general and ENT surgery: predictive value of a clinical multivariate risk index. Br J Anaesth 1998; 80: 140-6.

13. Timmermann A, Russo SG, Rosenblatt WH, et al. Intubating laryngeal mask airway for difficult out-of-hospital airway management: a prospective evaluation. Br J Anaesth 2007; 99: 286-91.

14. Kheterpal S, Martin L, Shanks AM, Tremper KK. Prediction and outcomes of impossible mask ventilation: a review of 50,000 anesthetics. Anesthesiology 2009; 110: 891-7.

15. Keller C, Brimacombe J, Lirk P, Puhringer F. Failed obstetric tracheal intubation and postoperative respiratory support with the ProSeal laryngeal mask airway. Anesth Analg 2004; 98: $1467-$ 70.

16. Baxter S, Brooks A, Cook T. Use of a Proseal LMA for maintenance after failed intubation during a modified rapid sequence induction. Anaesthesia 2003; 58: 1132-3.

17. Cook TM, Brooks TS, Van der Westhuizen J, Clarke M. The Proseal LMA is a useful rescue device during failed rapid sequence intubation: two additional cases. Can J Anesth 2005; 52: $630-3$.

18. Nixon T, Brimacombe J, Goldrick P, McManus $S$. Airway rescue with the ProSeal laryngeal mask airway in the intensive care unit. Anaesth Intensive Care 2003; 31: 475-6.

19. Han TH, Brimacombe J, Lee EJ, Yang HS. The laryngeal mask airway is effective (and probably safe) in selected healthy parturients for elective Cesarean section: a prospective study of 1067 cases. Can J Anesth 2001; 48: 1117-21.

20. Combes $X$, Le Roux B, Suen $P$, et al. Unanticipated difficult airway in anesthetized patients: prospective validation of a management algorithm. Anesthesiology 2004; 100: 1146-50.

21. Batra $Y K$, Panda NB, Rajeev S. Airway rescue with laryngeal mask airway during sclerotherapy of a large arteriovenous malformation in the oral and maxillofacial region. Paediatr Anaesth 2006; 16: 894-5.

22. Matioc AA, Olson J. Use of the Laryngeal Tube in two unexpected difficult airway situations: lingual tonsillar hyperplasia and morbid obesity. Can J Anesth 2004; 51: 1018-21.

23. Tse JC, Rimm EB, Hussain A. Predicting difficult endotracheal intubation in surgical patients scheduled for general anesthesia: a prospective blind study. Anesth Analg 1995; 81: 254-8.

24. El-Ganzouri AR, McCarthy RJ, Tuman KJ, Tanck EN, Ivankovich $A D$. Preoperative airway assessment: predictive value of a multivariate risk index. Anesth Analg 1996; 82: 1197-204.

25. Shiga T, Wajima Z, Inoue T, Sakamoto A. Predicting difficult intubation in apparently normal patients: a meta-analysis of bedside screening test performance. Anesthesiology 2005; 103: 429-37.

26. Krobbuaban B, Diregpoke $S$, Kumkeaw S, Tanomsat M. The predictive value of the height ratio and thyromental distance: four predictive tests for difficult laryngoscopy. Anesth Analg 2005; 101: $1542-5$

27. Lundstrom LH, Moller AM, Rosenstock C, Astrup G, Wetterslev J. High body mass index is a weak predictor for difficult and failed tracheal intubation: a cohort study of 91,332 consecutive patients scheduled for direct laryngoscopy registered in the Danish Anesthesia Database. Anesthesiology 2009; 110: 266-74.

28. Huh J, Shin HY, Kim SH, Yoon TK, Kim DK. Diagnostic predictor of difficult laryngoscopy: the hyomental distance ratio. Anesth Analg 2009; 108: 544-8.

29. Khan ZH, Kashfi A, Ebrahimkhani E. A comparison of the upper lip bite test (a simple new technique) with modified Mallampati classification in predicting difficulty in endotracheal intubation: a prospective blinded study. Anesth Analg 2003; 96: 595-9.

30. Eberhart LH, Arndt C, Cierpka T, Schwanekamp J, Wulf H, Putzke $C$. The reliability and validity of the upper lip bite test compared with the Mallampati classification to predict difficult laryngoscopy: an external prospective evaluation. Anesth Analg 2005; 101: 284-9. 
31. Naguib M, Scamman FL, O'Sullivan C, et al. Predictive performance of three multivariate difficult tracheal intubation models: a doubleblind, case-controlled study. Anesth Analg 2006; 102: 818-24.

32. Langeron $O$, Masso E, Huraux $C$, et al. Prediction of difficult mask ventilation. Anesthesiology 2000; 92: 1229-36.
33. Yildiz TS, Solak M, Toker K. The incidence and risk factors of difficult mask ventilation. J Anesth 2005; 19: 7-11.

34. Kheterpal $S$, Han $R$, Tremper $K K$, et al. Incidence and predictors of difficult and impossible mask ventilation. Anesthesiology 2006; 105: 885-91. 